\title{
Microbial Communities and Associated Mineral Fabrics in Altamira Cave, Spain
}

\author{
Soledad Cuezva $^{1}$, Sergio Sanchez-Moral ${ }^{1}$, Cesareo Saiz-Jimenez ${ }^{2}$, Juan Carlos Cañaveras ${ }^{3}$
}

\begin{abstract}
:
Cuezva S., Sanchez-Moral S., Saiz-Jimenez C. and Cañaveras J.C. 2009. Microbial Communities and Associated Mineral Fabrics in Altamira Cave, Spain. International Journal of Speleology, 38 (1), 83-92. Bologna (Italy). ISSN 0392-6672.

Evidences of microbial colonizations were observed in Altamira Cave, Spain. These consisted of distinct small coloured colonies, both on walls and ceiling, mainly located in the area near the cave entrance, which progressed until reaching the Polychromes Hall. The colonizations were characterized by a high morphological and microstructural variability and related to biomineralization processes. Two main types of $\mathrm{CaCO}_{3}$ deposits were related to the colonies: rosette- or nest-like aggregates of rhombohedral calcite crystals, and spheroid to hemispheroid $\mathrm{CaCO}_{3}$ elements. Colonies distribution seems to be controlled by microenvironmental conditions inside the cavity. The areas of the cave showing higher temperature, relative humidity, and $\mathrm{CO}_{2}$ concentration fluctuations presented a minor biomineralization capability.
\end{abstract}

Keywords: Geomicrobiology, biomineralization, vaterite, Altamira Cave

Received 29 October 2008; Revised 9 December 2008; Accepted 10 December 2008

\section{INTRODUCTION}

Caves are considered extreme sites for the life and many of them constitute oligotrophic environments (Northup \& Lavoie, 2001; Barton et al., 2004, 2007). The absence of light prevents primary production of organic matter by phototrophic microorganisms and therefore cave primary productivity depends on chemolithoautotrophic microorganisms (Sarbu et al., 1996; Porter et al., 2009). However, in shallow caves considerable organic matter input takes place, especially through infiltration waters, favouring the growth of heterotrophic bacteria (Groth \& SaizJimenez, 1999; Saiz-Jimenez \& Hermosin, 1999). The role of these bacteria in the karstic ecosystems is important since they are able to colonize rock surfaces and to use a wide range of organic and inorganic compounds as energy sources.

Evidences of microbial activity were identified in Altamira Cave, Spain. Near the entrance, small coloured colonies, visible by the naked eye, developed on the walls and ceiling cavity (SchabereiterGurtner et al. 2002; Portillo et al. 2008). These

1 Museo Nacional de Ciencias Naturales, CSIC, Departamento de Geologia, Jose Gutierrez Abascal 2, 28006-Madrid, Spain 2 Instituto de Recursos Naturales y Agrobiologia, CSIC, Apartado 1052, 41080-Sevilla, Spain

3 Departamento de Ciencias de la Tierra y del Medio Ambiente, Universidad de Alicante, Campus San Vicente del Raspeig,

Apartado 99, 03080-Alicante, Spain colonies are particularly interesting for the study of biomineralization processes due to stable microclimatic conditions in the cave, where bioinduced mineral fabrics are conserved without important diagenetic modifications (Cañaveras et al., 2006; Sanchez-Moral et al., 2006).

The aim of this work was twofold: i) to determine the relationship between bacterial colonizations and environmental conditions, and ii) to know the role of different microbial communities in mineral precipitation processes.

\section{MATERIALS AND METHODS}

Altamira Cave (Cantabria, Northern Spain) is located in the uppermost vadose zone of a tabular polygenic karst system that developed on Cretaceous, partly dolomitized calcarenitic limestones.

The record of diverse climatic parameters by means of an automatic monitoring system allowed to identify environmental fluctuations inside the cavity depending on the distance to the entrance and of the thickness of the overlying rock in each zone (Sanchez-Moral et al., 1999; Cuezva, 2008). The micro-environmental monitoring system consisted of a datalogger (dataTaker DT50, Grant Instruments Ltd., Cambridge, UK) with special sensors. The main microclimatic parameters measured within the cave were: air temperature and relative humidity (Pt-100 DIN1/5 and Rotronic Hygrometer), atmospheric pressure, carbon dioxide (Ventostat 8002, Telaire, Goleta, CA, USA) and ${ }^{222} \mathrm{Rn}$ concentrations (AB5 Continuous Passive Radon 
Detector, Pylon, Ottawa, Canada) in the air of the different halls (Kitchen Hall, Crossing, Polychromes Hall, Walls Hall, and Grave Hall).

Sampling of colonies were carried out in the walls and ceiling near the cave entrance, where a higher colonization and diversity was found (Figure 1). These colonies developed over different types of materials: host rock, speleothems, pigments and clay patches covering the host-rock. Thirty two representative samples were studied. They were selected according to their macroscopic features (size, colouration, wet conditions, etc.), substrata (host rock, speleothems, etc.) and the environmental conditions, including distance from the entrance. Samples were collected aseptically using sterilized instruments and were transported and stored at $5^{\circ} \mathrm{C}$ until they were examined at the laboratory.

For characterization of the colonies and associated mineral fabrics, mineralogical, geochemical and petrographic analyses were carried out. The semiquantitative mineral composition of the different substrata and mineral deposits was determined by X-ray diffraction (XRD) with a Philips PW-1710. Textural and microstructural characterization of the different microbial colonies was performed using a Nikon ECPOL-600 polarizing microscope, a Philips Quanta 200 environmental scanning electron microscope (ESEM) with an Oxford EDAX attachment,

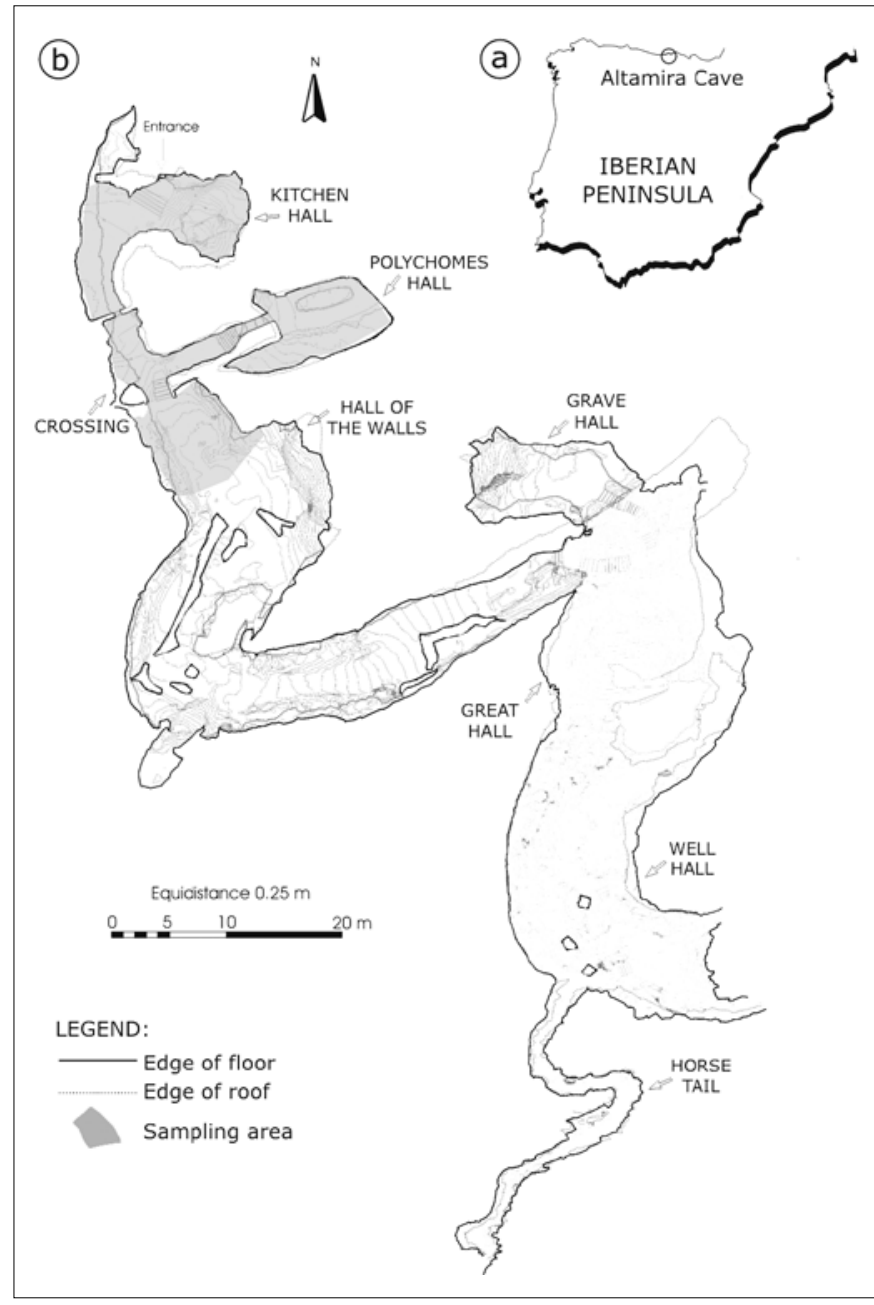

Fig. 1 a) Location of Altamira Cave (Cantabria, Northern Spain); b) Map of the cave and study area. and a Philips XL20 SEM. Energy-dispersive spectroscopy (EDS) analyses were carried out using a Philips EDAX PV9900 with a light element detector type ECON. ESEM allowed the observation and analysis without previous treatments of the colonies and associated mineral fabrics. To improve the photographic quality as well as EDS microanalysis, the samples were metallized and observed under high vacuum conditions, once described and characterized in thermo-hygrometric controlled conditions (Cuezva, 2008).

\section{Climate}

\section{RESULTS}

Altamira Cave has a stable microclimate (high thermo-hygrometric stability) throughout the year and a low energy exchange with the outside. Air temperature inside varies annually showing a sinusoidal pattern (Figure 2), with a thermal lag time depending on the outside temperature. Relative humidity remains fairly constant throughout the year, with values near saturation. Seasonal variations of $\mathrm{CO}_{2}$ concentration in the air cave are shown in Table 1.

Environmental changes were observed in some areas inside the cave, mainly depending on the distance to the entrance and the thickness of the host-rock. In general, the external influence gradually fades from outside to inside. In the exterior, the mean annual temperature was $14.35^{\circ} \mathrm{C}$ and the annual relative humidity was $85 \%$, with values above $90 \%$ most of the year. Table 1 shows that the cave presents smaller oscillation of annual temperature and relative humidity and higher $\mathrm{CO}_{2}$ concentration values in the most internal areas, such as Walls Hall $(7 \mathrm{~m}$ thickness of rock in the roof cover), Polychromes (7.5 $\mathrm{m}$ thickness) and Grave Halls (10 $\mathrm{m}$ thickness). In an intermediate area, Crossing (5 $\mathrm{m}$ thickness), and in the Kitchen Hall or Entrance ( $2.5 \mathrm{~m}$ thickness), the ranges of annual oscillation in temperature and relative humidity are higher than in the inner zones and air $\mathrm{CO}_{2}$ concentration values are lower.

\section{Colonization of the substratum and distribution of colonies}

In general, the substratum was wetted by condensation and dripping waters. These waters contained dissolved organic matter (Saiz-Jimenez \& Hermosin, 1999) and/or volatile organic compounds. Airborne microorganisms deposit on the wet rock and then cells adsorb to the substratum initiating colonization.

In Altamira Cave most visible bacterial growth adopts the form of round colonies. However, these colonies were not formed by only one or a few bacteria, but on the contrary they were complex communities composed of more than 20 different bacteria (Schabereiter-Gurtner et al., 2002; Portillo et al. 2008). Among the identified microorganisms a high diversity of sulfate-reducing bacteria and other metabolically active anaerobic bacteria were detected in the colonies (Portillo et al., 2008). These anaerobic bacteria are part of a multilayer biofilm and occupy 


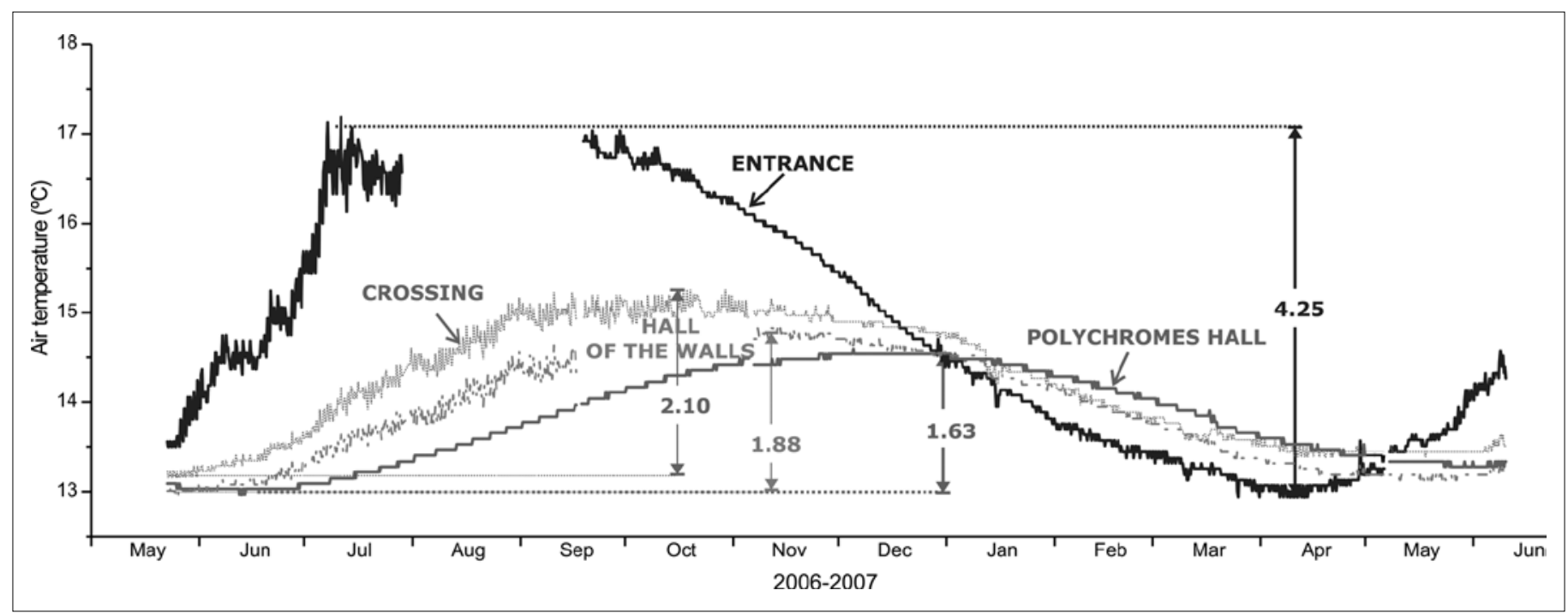

Fig. 2. Evolution of air temperature in Altamira Cave during an annual cycle in different parts of the cave. The numerical values correspond to the ranges of variation of annual temperature in each zone (in ${ }^{\circ} \mathrm{C}$ ).

Table 1. Ranges of annual variation of different climatic parameters in five areas monitored inside the cavity.

\begin{tabular}{|c|c|c|c|c|c|c|c|c|c|c|}
\hline & \multicolumn{2}{|c|}{$\begin{array}{l}\text { Entrance or } \\
\text { Kitchen Hall }\end{array}$} & \multicolumn{2}{|c|}{ Crossing } & \multicolumn{2}{|c|}{ Polychromes Hall } & \multicolumn{2}{|c|}{ Walls Hall } & \multicolumn{2}{|c|}{ Grave Hall } \\
\hline & $\min$ & $\max$ & $\min$ & $\max$ & $\min$ & $\max$ & $\min$ & $\max$ & $\min$ & $\max$ \\
\hline Temperature $\left({ }^{\circ} \mathrm{C}\right)$ & 12.94 & 17.19 & 13.16 & 15.26 & 12.97 & 14.60 & 12.95 & 14.83 & 12.95 & 13.21 \\
\hline $\mathrm{RH}(\%)$ & 92 & 100 & 98 & 100 & 98 & 100 & 98 & 100 & 98 & 100 \\
\hline $\mathrm{CO}_{2}$ in air (ppm) & 360 & 4660 & - & - & 572 & 5260 & 464 & 6330 & - & - \\
\hline
\end{tabular}

the oxygen-depleted microniches. Therefore, we are dealing with a heterogeneous biofilm where many different microorganisms interact and, consequently, different physicochemical microenvironments and concentration gradients of oxygen occur. For operational purposes, however, we will name these biofilms as colonies.

Colonization density decreased progressively towards the interior of the cave, being particularly intense in some areas of the walls and ceiling of the Kitchen
Hall and in the galleries of access to Polychromes and Walls Halls. Depending on their colour three types of microbial colonizations were present in the cave: white, yellow and grey colonies. The distribution pattern of the different colonies is described in Figure 3. Yellow colonies were predominant in the entrance and Kitchen Hall, being also abundant in the Crossing area, scarce in the Walls Hall and in the gallery giving access to Polychromes Hall, and nonexistent in this Hall. Grey colonies were predominant

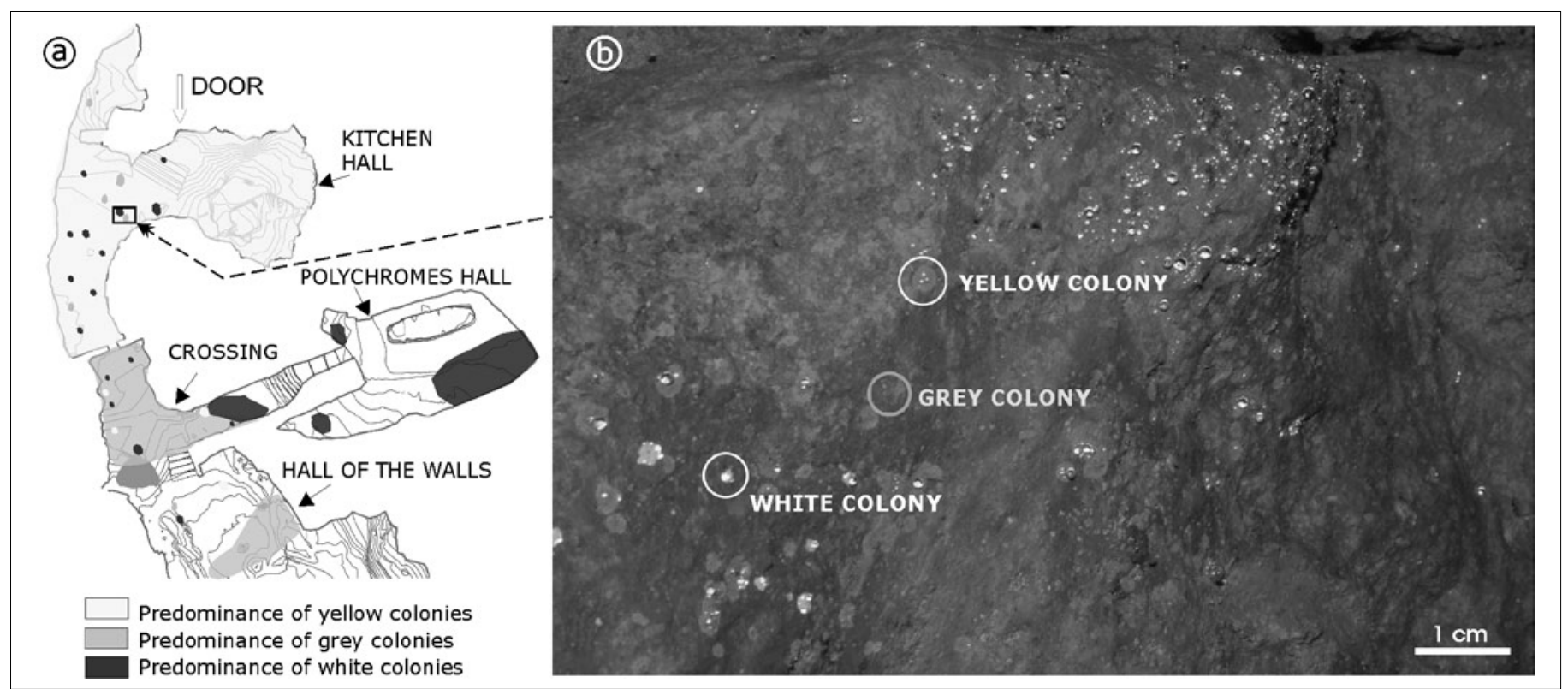

Fig. 3. a) Areas of preferential distribution of the different types of colonizations in Altamira Cave; b) View of a wall where the main types are observed: yellow-, grey- and white-colored colonies. 
in the Walls Hall, being also abundant mainly in the Crossing area and in the gallery to Polychromes Hall. White colonies were distributed along the cave, from the entrance to the Polychromes Hall. Small white colonies were located in more internal zones of the cave, where microenvironmental conditions are quite stable. The colonies occupy small voids of the rock, where water retention by surface tension forces is more effective. However, at present, they are the only one colonizing the Polychromes Hall, and are also abundant in the Crossing area and in the gallery conducting to Polychromes Hall. The colonized substrata were diverse: limestone/dolostone host rock (grey and white colonies), calcite speleothems (grey and white colonies), clays (yellow, grey, and white colonies) and Paleolithic pigments (mainly white colonies). Paleolithic pigments were basically of two types: red pigments composed of Fe-rich clays and Fe-oxides with minor amounts of terrigenous grains, and black pigments composed of clays, carbonate and abundant burnt wood-charcoal fragments (SanchezMoral et al., 1999).

\section{Colony structure}

When examined at low magnification ESEM, Altamira colonies exhibited a specific habit. Each one showed morphological and micro-structural variability of the different constituent elements (microorganisms, EPS -extracellular polymeric substances-, mineral biofabrics, etc.).

Yellow colonies were formed by round spots of 2-5 $\mathrm{mm}$ of diameter and showed circular to irregular contours, with apparent radial organization (Figure $4 a)$. Occasionally, the onlap of numerous colonies occupied more extensive irregular centimeter-size areas. On their surface they showed abundant water drops. At microscopic scale, yellow colonies were constituted by bundles of microorganisms with great variety of morphologies, from filamentous to spheroid or globular (Figure 4b; 5a and b). The apparent radial or fractal macroscopical organization observed at first glance was not clearly appreciated, but rather presented a disordered aspect. Associated mineral deposits were not found in these colonies.

Grey colonies, in general, showed smaller size that the yellow ones (diameter: 0.5-3 mm), circular contours and little relief (Figure 4c). Water drops were rarely observed on the colony surface. Contrary to the yellow ones, grey colonies were constituted by bundles of microorganisms clearly organized in a radial way starting from a central area generating a circular to irregular contour (Figure 4d; 5c and d). Microbes showed a high variety of morphologies, mainly filamentous and spheroids or globularcoccoids, commonly embedded by EPS. Associated mineral deposits were common.

White colonies presented a high variability in size and microstructure. In Polychromes Hall they have a small size $(<1 \mathrm{~mm})$ being located preferentially inside corrosion holes on bare rock (Figure 4e). In the entrance area white round colonies were larger in size (1.5-3 $\mathrm{mm}$ of diameter). Colonies usually showed a well-defined radial arrangement and high relief. Water drops on the colony surface were common. At microscopic scale, these colonies showed very defined branches having radial and divergent arrangement toward the exterior (Figure 4f; 5e and f). The branches constituted a dense network of thin interwoven bacterial filaments and globular microbial bodies of small size $(0.5 \mu \mathrm{m})$. When associated mineral deposits were abundant, these colonies were very similar to the grey ones.

\section{Mineral biofabrics}

Two main types of mineral deposits or fabrics were clearly associated to microbial colonies, specially to grey and white ones: i) small deposits of $\mathrm{CaCO}_{3}$ with morphology in rosette or nest (Figure 6c and d); and ii) spheroid or hemispheroidal elements constituted by $\mathrm{CaCO}_{3}$ (Figure 6e and f).

The rosette or nest-like fabrics were aggregates of 2-4 $\mu \mathrm{m}$ size subeuhedral to euhedral calcite crystals with radial arrangement and delineating an external pseudohexagonal contour. These aggregates showed a central hole whose diameter oscillates between 0.5 and $0.7 \mu \mathrm{m}$. They were generally leaning on the substratum, immersed in the biofilm (in occasions under it) (Figure 6a).

Calcium carbonate spheroid and hemispheroidal elements, with average diameter of 8-10 $\mu \mathrm{m}$ and frequently reaching diameters up to $15 \mu \mathrm{m}$, appeared sometimes coated by a filamentous structure. In many cases, a pit of 0.5 to $1 \mu \mathrm{m}$ of diameter was observed at the center of these spheroids. When the spheroid surface was not covered by a microbial film, it was irregular, showing rhombohedric shape, occasionally with corroded crystalline terminations. XRD analysis of samples containing spheroids indicated a calcite mineral composition; however it was not discarded that it could be vaterite (an unstable $\mathrm{CaCO}_{3}$ polymorph) that commonly shows spheroid habit and has similar dimensions (Ogino et al., 1987; Cañaveras et al., 1999; Sanchez-Moral et al. 2003).

Not all the colonies (either grey or white ones) presented mineralization. The variety of morphologies observed in the colonies linked to any type of mineralization were usually spatially associated. In general, this association was as follows:

(1) In colonies where the mineral component was scarce and disperse, the rosette or nest-like aggregates generally formed small patches. Over them, some spheroidal elements were observed (Figures 5c, 6a). In this case, the colony, either grey or white, presented a homogeneous colour.

(2) In colonies where the mineral component was predominant the rosette or nest-like aggregates formed a thin continuous bed on which scattered spheoridal elements were also present (Figure $6 b)$. In this case, the grey colony showed colour variation, presenting a more intense grey colour in the central zone. Such colour variation was not observed in the white colonies. 


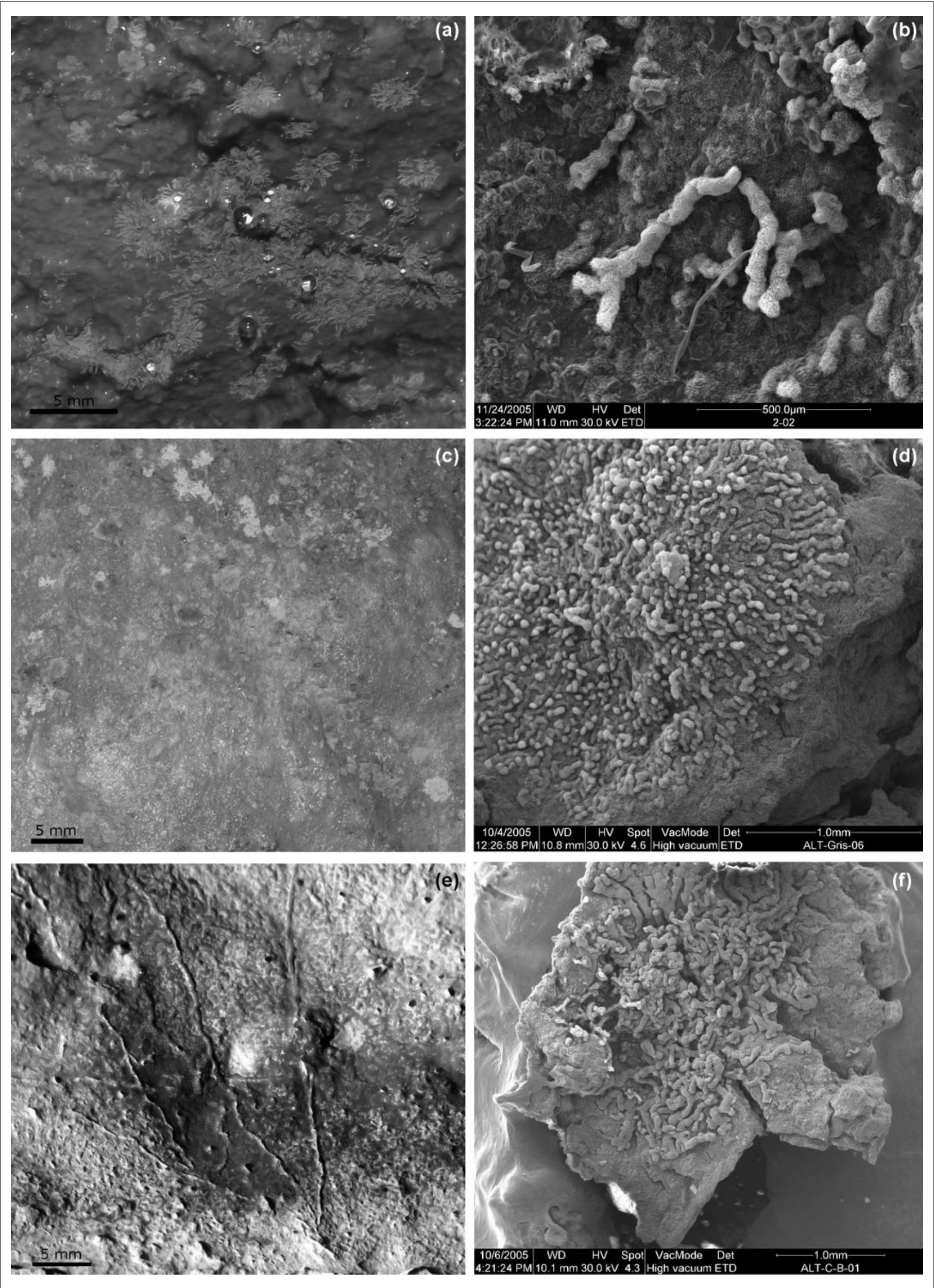

Fig. 4. Detail of the colonizations: a) yellow-colored colonies, c) grey-colored colonies, and e) white-colored colonies. ESEM microphotographs of the microstructural organization of: b) yellow, d) grey, and f) white colonies. 

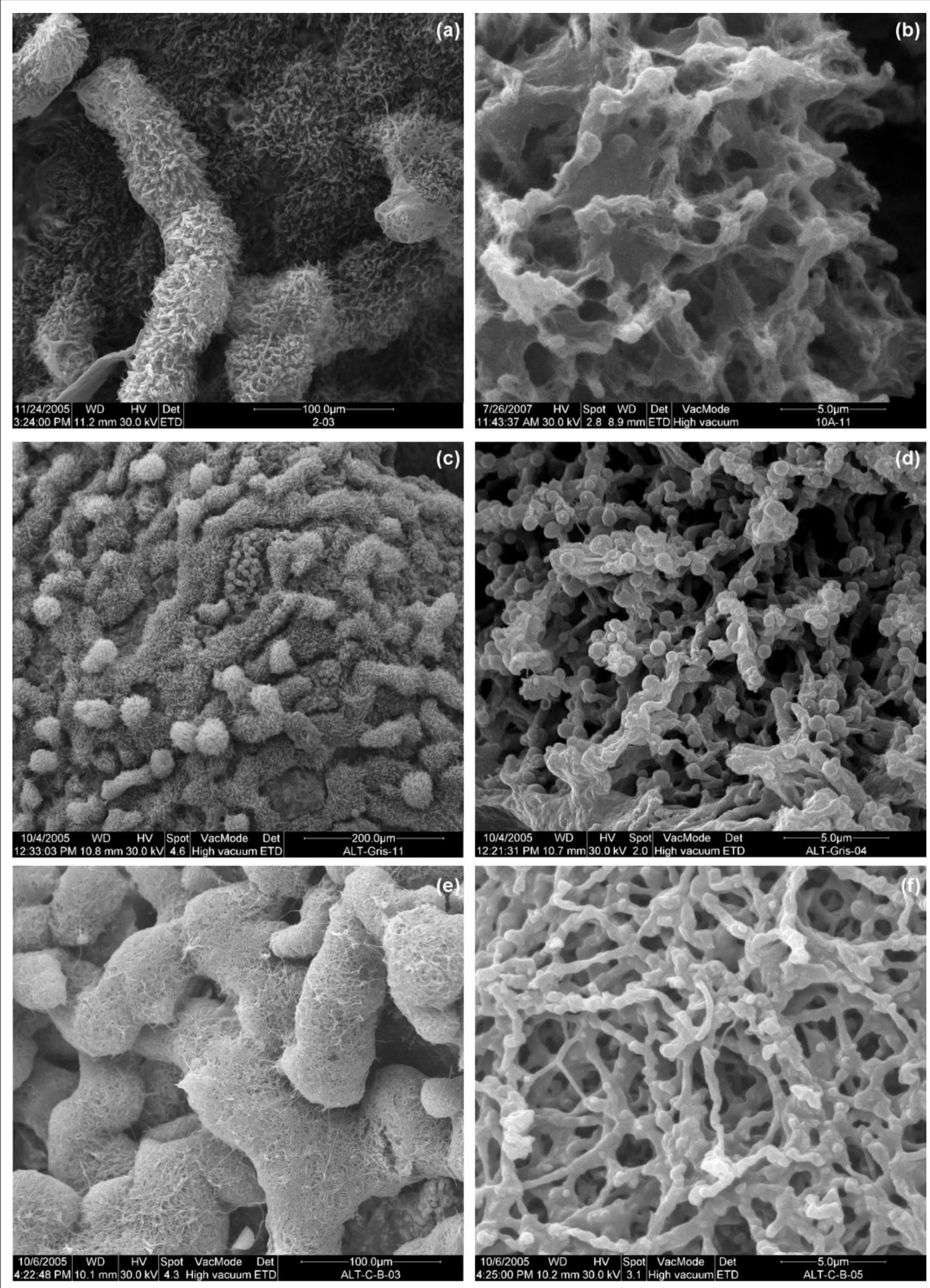

Fig .5. ESEM microphotographs of the microstructural organization of: a) yellow, c) grey, and e) white colonies. In detail, bundle of microorganisms of: b) yellow, d) grey, and f) white colonies. 

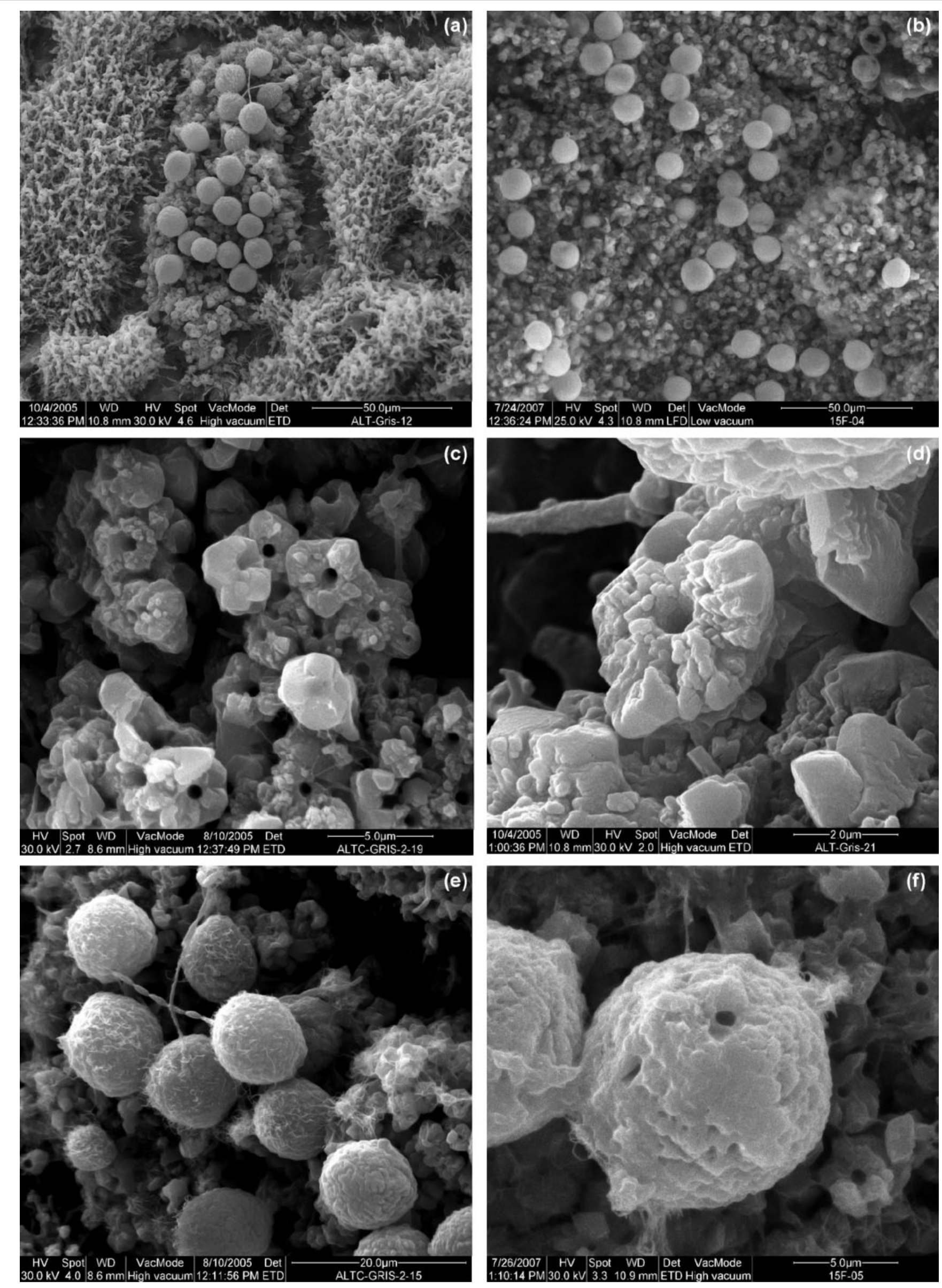

Fig. 6. ESEM microphotographs of the mineral fabrics: a) small patch of $\mathrm{CaCO}_{3}$ rosette or nest-like aggregates, and disperse spheroidal elements (grey colony); b) continuous bed formed of $\mathrm{CaCO}_{3}$ rosette or nest-like aggregates with disperse spheroidal elements (white colony); c) and d) in detail, deposits of $\mathrm{CaCO}_{3}$ in rosette or nest (grey colonies); e) and f) spheroid elements of $\mathrm{CaCO}_{3}$ (grey and white colony respectively). 


\section{DISCUSSION}

The distribution of the microbial colonies in a cave is controlled by the bioreceptivity (Guillitte, 1995) or susceptibility of the host material to be colonized, and depends on internal microenvironmental conditions (water availability, $\mathrm{pH}$, climatic conditions and nutrient sources) and petrological-textural parameters such as mineral composition, type of cement, porosity and rock permeability (Gorbushina, 2007).

Subterranean ecosystems, like karstic caves, are environments characterized by fairly constant temperature and air humidity values. Average annual temperature inside are similar to the external annual average and the humidity is generally close to saturation. However, distinct locations of the cave display environmental fluctuations as result of the distance to the entrance and the overlying rock thickness.

Cave entrances are directly influenced by external environmental conditions and present more nutrient inputs than inner locations, thus favoring microbial diversity. From an ecological point of view this area between epigean and hypogean systems constitutes an ecotone, a transition area among adjacent ecological systems (Hansen et al., 1988). The ecotone provides a major nutrient sources availability, since it is an area in which species of neighbouring habitats can coexist with those specific of the particular ecotone (Prous et al., 2004). This fact can favour a higher diversity in the epigean-hypogean transition than in the adjacent ecosystems (Lloyd et al., 2000).

Gaseous phase exchange processes are the main natural factor for the entrance and dispersion of microoganisms into the cavity. They especially occur during the summer season (June-September) and have a local character, directly linked to the entrance. During the summer season the entrance of Altamira Cave favours a direct external-internal exchange; warm and wet air entering in the cave results in the formation of clouds of water microparticles (hydroaerosols) that move toward the interior of the cave (Cuezva, 2008). Each hydroaerosol acts as potential adhesion nucleus for dust particles and spores in the air. The displacement of the aerosols increases liquid water and organic matter availability towards the interior of the cave favouring the development and dissemination of microbial colonies. Therefore, a colonization and proliferation of microorganisms is especially produced in the transitional zone, where energy exchange rate and resource availability are higher. Furthermore, the presence in some water samples of diverse compounds such as oxalates (1 ppm), phosphates (1 $\mathrm{ppm})$, formates $(0.5 \mathrm{ppm})$, dissolved organic matter (Saiz-Jimenez \& Hermosin, 1999), and bacteria (Laiz et al., 1999), suggests that water is also a vehicle for the arrival of microorganisms and organic matter to the interior of the cave.

The major bacterial components of the different colonies observed on the walls and ceiling of Altamira Cave were previously reported (Schabereiter-Gurtner et al., 2002; Portillo et al., 2008). They used culturedindependent techniques completing in this way studies using culturing-dependent strategies (Groth \& Saiz-Jimenez., 1999; Cañaveras et al., 1999).

Microbiological studies revealed that Proteobacteria represented by far the most important bacterial group within the active microbial community in Altamira Cave colonies (Portillo et al., 2008). Proteobacteria is a versatile phylum which was described as dominant in cave-dwelling communities exposed to high levels of human impact (Ikner et al., 2007). Lascaux Cave, an extremely disturbed environment, showed practically a unique colonization by Proteobacteria (Bastian et al., 2009). The dominance of Proteobacteria is then indicative of enhanced nutrient availability in epigeanhypogean transition zone in Altamira Cave.

Two main mineral fabrics are usually associated to both white and grey colonies; rosette- or nestlike aggregates and spheroid elements. Both, white and grey colonies have in common a high number of actinobacteria members in their DNA library $(33.3 \%$ for white and $25 \%$ for grey colonies) as reported by Portillo (2007). Cañaveras et al. (1999) pointed out the ability of actinobacteria to precipitate $\mathrm{CaCO}_{3}$ and their role in the colonization of speleothems and cave rock surfaces. Although the $\mathrm{CaCO}_{3}$ fabrics associated to the microbial colonies are not quantitatively significant, their study has great relevance, since they can be important deterioration agents, when are located near art rock representations (Cañaveras et al., 2001).

The colonies act as condensation points of water, where the water vapour is adsorbed quickly by the colony and retained during long periods of time on the rock surface (Figure $3 b$ ). This water may be related to changes or chemical reactions that, under certain conditions, can induce bioprecipitation as well as processes of mineral dissolution (Krumbein et al., 2003; Brehm et al., 2005).

Likewise, the microorganisms are able to create local microenvironmental conditions that might induce high oversaturation in $\mathrm{CaCO}_{3}$ of interstitial water. Many of the microorganisms previously identified in Altamira Cave were able to induce precipitation of $\mathrm{CaCO}_{3}$ in laboratory conditions (Cañaveras et al., 1999; Sanchez-Moral et al., 2003), probably due to their metabolic activity that promotes an increase in the alkalinity of the colony microenvironment and creates localized oversaturation conditions. Water samples in contact with bacterial colonies in the Polychromes Hall ceiling show lower $\mathrm{PCO}_{2}$ values, $\mathrm{Ca} / \mathrm{Mg}$ ratio, and both calcium and bicarbonate ion contents than dripping waters (Sanchez-Moral et al., 2003). In addition, it was observed that condensation water in contact with colonies has lower $\mathrm{PCO}_{2}$ than cave air. This could be indicative of the metabolic activity of some chemolithotrophs and of the generation of microbially conditioned confined microenvironments in the colonies (Portillo et al., 2008).

Rosette- or nest-like aggregates in Altamira Cave has been related to bacteria (Cañaveras et al., 1999). Specifically, this study concluded that these fabrics were intimately related to the presence of organic matter and their sizes, structure, arrangement and composition seem to be indicative of a biological origin. 
Recent ESEM observation revealed the relationship of these mineral deposits with the microbial colonies. These fabrics were partially covered by microbial filaments and/or EPS and they are part of the structure of the colony, so that they probably are generated under the biofilm constituted by a network with different branched structures.

The similarity of $\mathrm{CaCO}_{3}$ spheroid elements with vaterite spherulites in terms of size and morphology is evident (Giralt et al., 2001; Sanchez-Moral et al., 2003). Mineralogical analysis has not allowed the identification of vaterite, however the presence of this crystalline phase cannot be discarded due to the limitations of the identification method (XRD) for some elements with a reduced abundance in the sample and with such a degree of instability (Ogino et al., 1987; Sanchez-Moral et al., 2003). Vaterite is a metastable $\mathrm{CaCO}_{3}$ polymorph that habitually consists in small spheroid or globular morphologies and that at ambient temperature becomes calcite (stable polymorph). The existence of poorly-developed rhomboedral faces in some spheroid surfaces suggest that some vaterite spherules are partially or totally transformed into calcite aggregates or rhombohedric crystals. The formation mechanisms are not completely known (Friedman, 1997) but several authors indicate that bacterial activity seems to be necessary for the formation of vaterite aggregates (Giralt et al., 2001; Braissant et al., 2003; Sanchez-Moral et al., 2003; Rodriguez-Navarro et al., 2007) although bacterial vaterite precipitation is not strain-specific (Groth et al., 2001; Cacchio et al., 2003).

Laboratory experiments with cultivable Actinobacteria isolated from Altamira Cave resulted in the precipitation of crystalline aggregates of vaterite, using both liquid and solid (agar) culture media. Therefore, the capability of these bacteria to precipitate vaterite was evidenced (Laiz et al., 1999, Sanchez-Moral et at., 2003). This bioinduced vaterite displays a spheroidal morphology and around $10 \mu \mathrm{m}$ diameter (Sanchez-Moral et al., 2003). The similarity between experimental and natural spherical particles of the cave can be considered as a demonstration of an active process of bacterial carbonate precipitation. We think that the close relationship between biofilm and spherical $\mathrm{CaCO}_{3}$ observed in the colonies also suggest a biological origin for vaterite. Precipitation of carbonates may thus be promoted by heterogeneous nucleation on biological substrata (e.g. macromolecules that are constituents of bacterial cell membranes). They may act as a nucleation template for calcite/ vaterite. Vaterite could be considered as a spherical biomineral structure synthesized through microbial activity

\section{CONCLUSIONS}

The microbial communities of the Altamira Cave are diverse and quite complex, mainly showing a heterotrophic character and a biomineralization capability. Their distribution is mainly controlled by microenvironmental conditions. In general, they are widespread in areas near to the cave entrance, where major matter and energy transfer processes with the exterior are recorded. In particular, in Altamira Cave the areas characterized by higher microenvironmental parameter fluctuations ( $\mathrm{T}, \mathrm{HR}$, $\mathrm{CO}_{2}$ ) show higher microbial communities variability and lower biomineralization capability.

Basically two types of $\mathrm{CaCO}_{3}$ mineral fabrics mainly associated to white and grey colonies have been described. The origin of these precipitates is clearly related to bacterial activity. The microorganisms generate local environmental modifications inside the colony that favour the precipitation of $\mathrm{CaCO}_{3}$. However, the mechanism that favours the formation of each morphology or mineral fabric is still unknown. Further studies based on cultivation in natural conditions and isotopic analysis of the different elements will allow discriminating the mechanisms of mineral bioprecipitation that take place in the microbial colonies in Altamira Cave.

\section{ACKNOWLEDGMENTS}

This research was supported by the Spanish Ministry of Education and Science, project CGL2006$11561 /$ BTE and CGL2006-07424/BOS. This is a TCP CSD2007-00058 paper. J.A. Lasheras, Director of Altamira Cave Research Centre and Museum and all museum staff are acknowledged for their collaboration throughout the whole research period. Mineralogical analyses were conducted with the assistance of $R$. González (MNCN-CSIC).

\section{REFERENCES}

Barton H.A., Taylor M.R. \& Pace N.R., 2004 - Molecular phylogenetic analysis of a bacterial community in an oligotrophic cave environment. Geomicrobiology Journal, 21: 11-20.

Barton H.A., Taylor N.M., Kreate M.P., Springer A.C., Oehrle S.A. \& Bertog J.L., 2007 - The impact of host rock geochemistry on bacterial community structure in oligotrophic cave environments. International Journal of Speleology, 36: 93-104.

Bastian F., Alabouvette C. \& Saiz-Jimenez C., 2009. Bacteria and free-living amoeba in Lascaux Cave. Research in Microbiology (in press).

Braissant O., Cailleau G., Dupraz C. \& Verrecchia E.P., 2003 - Bacterially induced mineralization of calcium carbonate in terrestrial environments: The role of exopolysaccharides and amino acids. Journal of Sedimentary Research, 73: 485-490.

Brehm U., Gorbushina A.A. \& Mottershead D., 2005 - The role of microorganisms and biofilms in the breakdown and dissolution of quartz and glass. Palaeogeography, Palaeoclimatology and Palaeoecology, 219:117-129.

Cacchio P., Ercole C., Capuccio G. \& Lepidi A., 2003 - Calcium carbonate precipitation by bacterial strains isolated from a limestone cave and from a loamy soil. Geomicrobiology Journal, 29: 85-98.

Cañaveras J.C., Sanchez-Moral S., Sanz-Rubio E., Bedoya J., Soler V., Groth I., Schumann P., Laiz L., Gonzalez I. \& Saiz-Jimenez C., 1999 - Microbial communities associated to hydromagnesite and needle fiber aragonite deposits in a karstic cave (Altamira, Northern Spain). Geomicrobiology Journal, 16: 9-25. 
Cañaveras J.C., Sanchez-Moral S., Soler V. \& Saiz-Jimenez C., 2001 - Microorganisms and microbially induced fabrics in cave walls. Geomicrobiology Journal, 18: 223-240.

Cañaveras J.C., Cuezva S., Sanchez-Moral S., Lario J., Laiz L., Gonzalez J.M. \& Saiz-Jimenez C., 2006 - On the origin of fiber calcite crystals in moonmilk deposits. Naturwissenschaften, 93: 27-32.

Cuezva S., 2008 - Dinámica microambiental de un medio kárstico somero (Cueva de Altamira, Cantabria): microclima, geomicrobiología y mecanismos de interacción cavidad-exterior. $\mathrm{PhD}$ thesis, Universidad Complutense de Madrid: 320 p.

Friedman G.M., 1997 - A re-examination of reported lacustrine vaterite in Holkam Lake, Norfolk, UK-Opinion. Journal of Sedimentary Research, 67: 616.

Giralt S., Juliá R. \& Klerkx J. 2001 - Microbial biscuits of vaterite in lake Issyk-Kul (Republic of Kyrgyzstan). Journal of Sedimentary Research, 71: 430-435.

Gorbushina A., 2007 - Life on the rocks. Environmental Microbiology, 9: 1613-1615.

Groth I. \& Saiz-Jimenez C., 1999 - Actinomycetes in hypogean environments. Geomicrobiology Journal, 16: $1-8$.

Groth I., Schumann P., Laiz L., Sanchez-Moral S., Cañaveras J.C. \& Saiz-Jimenez C., 2001 Geomicrobiological study of the Grotta dei Cervi, Porto Badisco, Italy. Geomocrobiology Journal, 18: 241258.

Guillitte O. 1995 - Bioreceptivity: a new conceptfor building ecology studies. Science of the Total Environment, 167: 215-220.

Hansen A.J., di Castri F., Naiman R.J., 1988 - Ecotones: what and why? In: di Castri, F., Hansen, A.J., Holland, M.M. (Eds.), A New Look at Ecotones. Biology International, IUBS, Paris, France, Special Issue 17, pp. 9-46.

Ikner L.A., Toomey R.S., Nolan G., Neilson J.W., Pryor B.M. \& Maier R.M., 2007 - Culturable microbial diversity and the impact of tourism in Kartchner Caverns, Arizona. Microbial Ecology, 53: 30-42

Krumbein W.E., Brehm U., Gerdes G., Gorbushina A.A., Levit G.S. \& Palinska K.A., 2003 - Biofilm, biodictyon, biomat, microbialites, oolites, stromatolites, geophysiology, global mechanisms, parahistology. In: Krumbein W.E., Paterson D.M. \& Zavarzin G.A. (Eds). Fossil and Recent Biofilms. Dordrecht, the Netherlands: Kluwer Academic Publishers, 1-27.

Laiz L., Groth I., Gonzalez I. \& Saiz-Jimenez C., 1999 - Microbiological study of the dripping waters in Altamira cave (Santillana del Mar, Spain). Journal of Microbiological Methods, 36: 129-138.

Lloyd K.M., McQueen A.A., Lee B.J., Wilson R.C.B., Walker S., Wilson J.B., 2000 - Evidence on ecotone concepts from switch, environmental and anthropogenic ecotones. Journal of Vegetation Science 11: 903-910.
Northup D.E. \& Lavoie K.H., 2001 - Geomicrobiology of caves: A review. Geomicrobiology Journal, 18: 199220.

Ogino T., Suzuki T. \& Sawada R., 1987 - The formation and transformation mechanism of calcium carbonate in water. Geochimica and Cosmochimica Acta, 51: 27572767.

Porter M.L., Engel A.S., Kane T.C. \& Kinkle B.K., 2009 - Productivity-diversity relationships from chemolithoautotrophically based sulfidic karst systems. International Journal of Speleology, 38 (1): 27-40.

Portillo M.C., 2007: Aplicación de técnicas moleculares basadas en ADN y ARN al estudio de la diversidad microbiana en la Cueva de Altamira (Cantabria, España). PhD Thesis, Universidad de Sevilla: $312 \mathrm{p}$.

Portillo M.C., Gonzalez J.M. \& Saiz-Jimenez C., 2008 Metabollically active microbial communities of yellow and grey colonizations on the walls of Altamira Cave, Spain. Journal of Applied Microbiology, 104: 681-691. Prous X., Lopes Ferreira R. \& Parentoni R., 2004 Ecotone delimitation: Epigean-hypogean transition in cave ecosystems. Austral Ecology, 29: 374-382.

Rodriguez-Navarro C., Jimenez-Lopez C. RodriguezNavarro A., Gonzalez-Muñoz M.T. \& Rodriguez-Gallego M., 2007. Bacterially mediated mineralization of vaterite. Geochimica et Cosmochimica Acta, 71: 1197-1213.

Saiz-Jimenez C. \& Hermosin B., 1999 - The nature of the organic matter present in dripping waters from Altamira Cave. Journal of Analytical and Applied Pyrolysis, 49: 337-347.

Sanchez-Moral S., Soler V., Cañaveras J.C., Sanz E., Van Grieken R. \& Gysels K., 1999 -Inorganic deterioration affecting the Altamira Cave, $N$ Spain: quantitative approach to wall-corrosion (solutional etching) processes induced by visitors. Science of The Total Environment, 243: 67-84.

Sanchez-Moral S., Cañaveras J.C., Laiz L., SaizJimenez C., Bedoya J. \& Luque L., 2003 -Biomediated precipitation of calcium carbonate metastable phases in hypogean environments: a short review. Geomicrobiology Journal, 20: 491-500.

Sanchez-Moral S., Gonzalez J.M., Cañaveras J.C., Cuezva S., Lario J., Cardell C., Elez J., Luque L. \& Saiz-Jimenez C., 2006 - Procesos de precipitación mineral bioinducidos en sistemas kársticos subterráneos: breve revisión y nuevas tendencias. Estudios Geológicos, 62: 43-52.

Sarbu S.M., Kane T.C., Kinkle B.K., 1996 - A chemoautotrophically based cave ecosystem. Science, 272: 1953-1955.

Schabereiter-Gurtner C., Saiz-Jimenez C., Piñar G., Lubitz W. \& Rölleke S., 2002 - Altamira Cave Paleolithic paintings harbor partly unknown bacterial communities. FEMS Microbiology Letters, 211: 7-11. 